\title{
The Architecture plan of Qutb Complex (Delhi) and its Decoration Analysis
}

\author{
Sonia Nasir Khan \\ Lecturer \\ Department of Art \& Design \\ Women University, Multan. \\ Muhammad Ahsan Bilal \\ Lecturer \& PhD Scholar \\ Research Centre, \\ University College of Art \& Design, \\ University of Punjab, Lahore
}

\begin{abstract}
:
The Qutb complex in Delhi contains the array of early Sultanate Period Muslim monuments that demonstrate the earliest artwork development stage of Muslim monuments from 12 to $13^{\text {th }}$ century especially the architecture style and the stone carving patterns that exists in the monuments of this complex like in masjid Quwat-ul Islam (1191 A.D), Qutab Minar (1202 A.D), Illtutmish Tomb (1235 A.D), Alai Darwaza (1311 A.D). These splendid monuments have a new architectural style in India. Their beautiful carvings in red sandstone and marble that includes the patterns of arabesque style along with Kufic and Naskh calligraphy, the delicate floral and geometric patterns along with some Hindu motifs that depicts the earliest amalgamation of Hindu and Islamic architecture within the subcontinent. This paper not only aim to explore the architectural plan of this Qutb complex under different monarchs but also the decoration of this Qutb complex, its analysis and the aesthetic changes of design after the amalgamation of two different cultures. This complex is famous not only for its architecture but also for varieties of decorative arts. This paper also attempts to discover not only aesthetics but also the traditional and regional logic for using these motifs. This explorative study is from available historical data and literature. In the end concludes that the amalgamated motifs of decoration was excellent experiment and first addition in the design vocabulary of Indo-Muslim art and architecture. These designs provide serenity and majestic feelings to these monuments and in whole to Qutb complex.
\end{abstract}

Keywords: architecture, motifs, varieties, traditional, regional, logic

\section{Introduction}

First contact of Muslim in subcontinent is $21^{\text {st }}$ June 712 A.D through the routes of the sea on the seashore of Debel. There from same time from Afghanistan more Muslim rulers continued attacking on India and each time extend their territory so much so by 977 Sabutageen of Ghaznvai father of Mahmood Gaznavi invaded India along bank of River Indus but Delhi which was almost center of India remained unthreatened so much so Delhi 
was little bit threaten 1022 when Mahmood Ghaznavi invaded lots of portion of Pakistan and declared his state. After the death of Ghaznavi 100 A.D., the Ghaznavi kingdom became feeble so Ghori's became next all territory of Pakistan and one of his major ruler whose name was Shahbudeen Ghori . He captured Delhi in 1191 by defeating Prithvi Raj and captured Delhi and Muslim kingdom North of India occupied. So Shahbudeen Ghori send Aubak ${ }^{1}$ and made him Governor of Delhi (1191). Prithvi Raj defeated in Bathinda and brought Ajmar for prison and death by Shahbudeen governor's Aubak. However in south some are quiet stronger and made small state. Northwest of India had Muslims. From 1191 Muslim architecture started. In 1206 Ghori was murdered in Sindh. General Aubuk (1191-1206) became govern $1^{\text {st }}$ Sultan. After 1206 from Aubak to Ibrahim Lodhi it is called Sultanic art or Pre-Mughal Architecture (from 1191-1526).

Through Sindh after northern portion in Sabutageen Ghazanavi made Lahore its capital. But Ghori made Delhi its capital in 1191. In 1191 as soon as Aubak capture Delhi he intelligent of fact that are one who rules Delhi will rule India as soon he became governor he tried to expand kingdom and was to make Muslims monuments who could proclaim supremacy of Islam from Delhi as were in India. So immediately he made congregational mosque and high in Delhi and called Masjid- e- Quwat ul Islam (Ist in Delhi). He started in 1193 this was made in the old Delhi. ${ }^{2}$ That was the first monument in the complex and also known as Qutb mosque. There are theories about its name either on the name of Aubak or name of saint of Baghdad Qutb - ud-din Ush (Qutb Sahib). Qutb Complex have array of monuments and buildings (Fig.1).First constructed by Aubak (slave dynasty). Complex was added by many rulers like Iltutmish ${ }^{3}$. Alauddin Khilji and later Feroz Shah Tughlaq and British. Important monuments areMasjid Quwat-ul-islam/Qutab Mosque, Qutb Minar, Alai Darwaza, Alai Minar, Iron Pillar, and Tomb of Iltutmish.

This study is based on the primary as well as the secondary sources of historical data and available relevant literature, and webpages for this qualitative research to explore the history of this research. The main objectives of the study is to explain the ancient complex historical site and relating monuments and to examine the main design varieties of this site. To search the Hindu and Muslim elements in this complex. To have better understanding of initial stages of Muslim artworks. The research support to give answers to questions like either the traditional and local blend supports the Muslim independent style or not and have symbolic meaning or just for aesthetics purpose? The historical data have been collected from the local and foreigners books that have written about this complex. There have been previous studies 
by R Nath, Flechier Banister, Percy Brown, JP Thomson, Catherine Asher related to the monuments of this Sultanate period. Archaeological survey of India explains the site of these monuments and historical facts of this monuments. However, this complex shows influence of two cultures. Lord Napier ${ }^{4}$ criticizes the mixing of Hindu and Muslim style and S. D. Sharma's also explains it as negative evaluation of the mixing of architectural forms. ${ }^{5}$ While Chaghatai ${ }^{6}$ and Doan Kuban's acknowledge the efforts of Muslims architecture style and that regional developments influenced by local traditions. ${ }^{7}$ Creswell believes that it's the labor of love $^{8}$ which makes Muhammedan architecture peculiar.Doan Kuban also observes that how

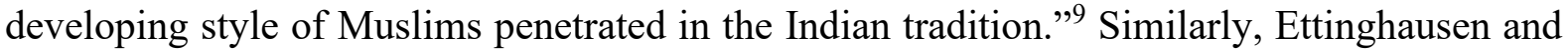
Grabar's explain how the central arch used in mosque just like Iranian iwan of arcuate style but in the trabeate style and stone medium preferred in north India. ${ }^{10}$ Later Michael Willis also noted that screen at Delhi is an example of Indian art put to Islamic usage. ${ }^{11}$ These points reflects two things the indigenous and foreign elements that these buildings reflect.Havell, believe that this mosque is temple version for Muslim rituals and lack Iranian or Central Asian influence. ${ }^{12}$ Fergusson explained as pillars are of Hindû and walls are of Muhammadan, architecture. ${ }^{13}$ Chagatai views its Indianised version of Seljuk architecture. ${ }^{14}$ Havel believes that that Muhammedan art is the impression belongs to local soil.

\section{a) Main Monument of Complex: Qutab Mosque}

When Ghori captured Delhi Prithvi raj was last Hindu ruler. Anang Pal Tamor build Qila Rai Pithora. Initailly named Lal kot later renamed by Prithvi Raj as Qila Rai Pathora. When Ghori captured he demolish Qila which consist of 27 Temples of material red sandstone and build mosque with this material on the same place and did not changed the name. In old Delhi place called Lal Kot. South of old Delhi is the place Lalkot where forte is. It was a strong forte. When Ghori defeated he ran towards Bathinda and after that he killed in Ajmar.

\section{i) Aubak Contributions}

Ghori soldier Aubak demolished all material and this material was used for masjid. It's the first mosque in Delhi. Simple mosque in beginning in trabeate construction. It's nothing just a rectangular courtyard surrounded by riwaq contained on three sides by rows of stone columns brought from 27 local Hindu and Jain temples. (Tappin 2003) Which had an eastern gateway and in the west there was a sanctuary (Fig. 2a). It's on the same place where Qila Rai Pathora was. Now just ruins. It's in red sandstone because this stone easily available around Delhi. Temple made of red sandstone and this is demolished and used for masjid. So 
Masjid is in red sandstone. Three riwaqs made from columns of Pithora by demolishing sculptures on the southern, eastern and northern and on west side sanctuary. The arrangement of the pillars of sanctuary was made more spacious and resolved into a series of bays with shallow domed roofs. The roof of sanctuary was supported by stone labs and labs supported by stone beams. All in red sandstone.Mosquehave 5 corbel domes build on minimum curves (Fig4a, b). The domed mezzanine chambers at its southeastern and northeastern corners ${ }^{15}$ have multiple functions either housed madrasas ${ }^{16}$, zenan khanas or private place for prestigious kings etc. and have private entrances decorated with figural sculptures. (Fig.4c). This Mosque was built in 1193 and continued in 1195. Build in three years. ${ }^{17}$ First Islamic building in India of dress stone ${ }^{18}$ along with a patchwork of older material. When he build this he was not satisfy because in this building neither Hindu element nor Muslim and mostly made by Hindu mansions.

Two years it remained same but in 1197 he added arch screen wall between courtyard and sanctuary. Arch screen huge kind of wall while one arch in center and two arches flanking the sides. It had total five arches and called as Maqsoora. (Figure 2a,3a)Each smaller arch had a clerestory above it, mainly for decorative purposes as it did not serve in any way the sanctuary behind it. The central arch height is 48 feet and in width ${ }^{19}$ its 21 feet almost, while outer four arches height were almost 28 feet. These are corbel arches made by Hindu masons (Fig.2 b).These arches have minute detail vegetal motifs inlay decoration. The facade is embroidered with carvings of floral devices and Quranic verses (Fig. 3b,c). The arches are not true arches and this ogee or s curve shape of the pointed arch may be derived from the Buddhist caves of the Barahar hills of Bihar and the Sarnath Stupas as Havell (1913) related the pointed arch with Buddhist temples. ${ }^{20}$ It started in 1197 and completed in 1199. With this addition it gives Muslim look as Muslim used this tradition from Madina and after Hazrat Usman martyrdom. This was made there and Aubak used this tradition from there and Hindu mansions made this and with this addition it look like Muslim architecture. Before its addition it's named as Qutab Mosque and after the addition of this arch it named as Quawatul Islam. Persian inscription still on the inner eastern gateway.Length and Breadth of the mosque was 212 x 150 feet during Aubak times ${ }^{21}$ and Ibn Abul-Ma'ali name on one of its ${ }^{22}$ western side courtyard pillar shows that he was guardian of this mosque.

In front of this screen in courtyard, there is pillar to show symbol of authority that Aubak became powerful. One and half inside and of 23 diameter. (Fig.3a,) Its Ashoka pillar ${ }^{23}$ but he removed lion sculpture. Iron pillar is $7 \mathrm{~m}$ in the courtyard and inscriptions on the pillar indicate that it was made during the reign of Chandragupta 11(4th century B.C)As Lal kot 
later renamed as Qila rai Pithora. Built by Anangpal Tomar - Tomar Rajput and last Hindu ruler of Delhi. He has also installed the iron pillar of Vishnu ${ }^{24}$ in the middle of the city. The same iron pillar seen today in Qutb complex.The pillar is symbol of progress of metallurgy in ancient India and is of $99 \%$ wrought iron. ${ }^{25}$ The fluted bell capital with its amalaka member is characteristics of Gupta architecture ${ }^{26}$

In 1199 Aubak composed a very lofted tower on south eastern corner and named Qutab Minar (238) (Fig.9b). 1199 Mosque without extension till Aubak reign and same year he laid foundation of Qutab Minar. The Islamic Ayat have been chiseled out in a very delicate and minute manner. He completed one storey of this Minar and died.

\section{ii) Iltutmish Contributions:}

Aubak died in 1210 in Lahore ${ }^{27}$ and then his son in law Sultan Shamsuddin Itutmish became Sultan. It's the first extension of the mosque. He enlarge the mosque from both sides and again 3 riwaq on eastern, southern and northern side and in which collected causeway 10 'feet while other side another sanctuary. Double heighted riwaq and center entrance in front and made two more sanctuary on either side of the sanctuary. He made same arch screen but three arches added. Now made doorways in the inner riwaq. Qutab minar now inside the Quwat-ul- Islam(Fig.7).

Iltumish comes and enlarge 450 feet in length \& 230 feet in breath. The breath of the causeway was 10 feet and height of causeway were $81 / 2$ feet and during Iltumish its three side's double it becomes 17 feet. $^{28}$ Area of arch of original mosque and area of double and breadth. Basic conception of Quwat ul Islam is basically the Muslim traditions of Maskoora. By the time of Iltutmish, the Mamluk Empire had stabilized enough that the Sultan could replace most of his conscripted Hindu masons with Muslims. This explains why the arches added under Iltutmish are stylistically more Islamic this time than the ones erected under Aubak's rule, also because the material used wasn't from demolished temples. These arches are of a very finely constructed red stone with Qur'anic verses inscribed upon them in Kufic and naskh calligraphic styles, and decorated with exquisite vegetal motifs.During Aubak the shape of arches is ogee curve but here changed to simple arc and with more firm curves but principally corbelled. ${ }^{29}$ However according to Qureshi, Iltutmish conquered Malwa and Ujjain, and destroyed the Mahakal Temple and the idols there and brought material to Delhi and used it at the entrance of this mosque. ${ }^{30}$ 


\section{iii) Alaudin Khilji Contributions:}

Alaudin Khilji did the second extension of the mosque when he became ruler he extend towards east, north and Western side he added sanctuary and just like other rulers he added 3 Masqoora. Highest one in the center and smaller on both sides (Fig. 8a).

Alai Minar of 87 feet but he planned to erect the minar of 500 feet.Alai minar is an incomplete monument within this complex. Alauddin conquered Deccan so he decided to make Alai minar of double height of Qutb minar. It's in the north of the Qutb minar. It has ramps instead of stairs. Windows are at regular quadrant heights for a gradual ramp to be made. The incomplete minaret stands in heaving rubble masonry with just a single storey ${ }^{31}$ that ceased to be constructed further after the sultan's death in AD 1316 (Fig.8b).

He also added four monumental gateways. 2 in east and 1 in north and one in south. Only Southern gate completed and all others remained incomplete and Southern Gateway named as Royal Gate or Alai Gate or Southern gateway (Fig.14a). In 1302 Khilji death. So important additions to the mosque done by Alauddin Khilji, also including the mosque formal entrance Alai Darwaza, in marble and red sandstone, and a court to the east of the mosque in $1300 \mathrm{AD}$. The length became 751 feet and breadth 430 feet during Khilji times and had twenty arches.

Now just ruins of Qutab Mosque (Fig.16b). Only Qutab Minar, Iltutmish tomb and Alai Darwaza is still remained.

\section{Decoration Analysis of Qutab Mosque:}

History of ornamenting the walls of mosque beginnings during Umayyad. Though from $7^{\text {th }}$, $8^{\text {th }}$ century floral and vegetal designs influence from Sassanid and Byzantine ${ }^{32}$, and geometric patterns in $9^{\text {th }}$ century that later help in floral abstraction became part of Muslim architecture design. Similarly Greek and Egyptian motifs like lotus, waterlily, rosette, acanthus, ${ }^{33}$ Muslim artist used such motifs in stylized form in harmony and symmetric order called arabesque before. But here the execution is in stone carving and yet symmetry is strictly observed. The patterns extends over a large space in an oblong scroll.Impression of natural foliage along with geometric designs is another Muslim decoration feature that one can observe here but with a change in execution that change due to Hindu masons influence like the Calligraphic stocks ends in buds and flower forms even in the first screen (Aubak Times) (Fig: 3c,6c) and they are experts in stone carvings. Facade screen beautiful decoration depicts the excellence of their craftsmanship and is noticeable in the vegetal scrolls, lotus patterns and in execution of the unfamiliar Quranic script in Nakshi on the free standing screen of 1191. 
Original façade build by Hindu mansions but later Muslim yetmotifs of both Hindu and Muslim motifs used in this mosque.

Rhythmic manner of filling given space with interlaced and confluent forms suited to the calligraphic character of Islamic design. Providing spiritual and aesthetic pleasure. Kufic inscription is another feature one can observe here in the monument of Sultanate period, which were generally comprised of Bismillah, Quranic verses, names of Allah. Facade of Quwwatul Islam Mosque, facade of Adhai-din-ka-Jhonpda Mosque, Ajmer are good examples of plaited Kufi style. Calligraphic stocks ends in buds and flower forms in Aubak times but during Iltutmish combination of square Kufic interwoven with Tughra characters ${ }^{34}$ As the Hindu masons are not expert in arcuate system. So instead of true arch with keystones. They created false arch of corbelling (Fig 2b) on façade in screen. But these are pointed arch. Pointed arch used on the façade in screen(Fig. 3b). The symbolic idea connected with pointed arch is that it appealed to the devout musalman man not because it was architecturally useful and beautiful but because it symbolizes the two fundamental concepts of his faith _ god is one and Muhammad is his prophet. It was the architectonic symbol of hands joined in prayer; it pointed the way to Mecca and to paradise and demonstrated mathematically the divine truth that all things converge towards to meet in One _ the inverse of Hindu proposition.Pointed arch and Calligraphy on façade gives an impression of upwards to downwards.(Fig.3b,c) Riwaq have motifs too present. The clear pictures of Hindu gods and deities like Shri Ganesh, Vishnu, Yaksha and symbols like kalash, temple wells and sacred lotus witnesses the Hindu origin of the building. Mainly the faces of Gods and deities are broken and rest all parts are maintained safe till now. The corridor is completely of Vedic stylehaving rectangular galleries with holy symbol engraved pillars(Fig.5). Thus the only thing, seeing the Arabic fonts on the wall, can be said is that the name Quwat-ul-Islam was given to one of the 27 temples left existing in a converted form. Here again one can see the trabeate system of post and lintel.

Brahmanical motifs like kalasa and lotus on pillar (Fig.6a, b) and hanging bells on the prayer hall column are also present. This ghantamala motif ${ }^{35}$ of bell and chain is Hindu Rai Pathora temple motif.Such Brahmanical motifs are symbol of abundance and overflowing prosperity.Grotesque faces known as 'kirtimukha', a common motif on Hindu temples also present. Similarly the in mosque the zenan khanas or royal rooms private entrance have decoration like lion and elephants that signifies royalty of Indic and Persian ate kingship ${ }^{36}$ that explains place meaning along with carve material use. (Fig.5 b) 
Circulardome and pillars on east colonnade (Fig.4a,b). Flat ceiling slabs and shallow corbelled domes taken bodily from some Hindu shrine. ${ }^{37}$ Hindu craftsman was set to work upon arabesque designs and Naskh characters ${ }^{38}$ during Aubak times but the arabesque designs are entirely Saracenic during Iltutmish times and introduced a combination of the square Kufic and the elaborate and intricately interwoven Tughra characters (Fig.7c).Dome ceiling resembles with $11^{\text {th }}$ and $12^{\text {th }}$ century Mount Abu Dilawara Jain temple that explains the trend and artwork influence of local craftsmen(Fig 19a,b). Dhamekh Stupa, Sarnath, $7^{\text {th }}$ century designs also resembles that depicts the local influence on designs (Fig.18).

\section{b) Other Main Monuments in the Qutab complex}

Qutb Minar 1199 A.D is important within the complex. Completed by 4 Monarchs: Qutb-uddin Aibak,Iltutmish,Khilji,Feroz Shah Tughlaq (1351- 1388). When completed it was only 4 storeys.Presently we see Qutb Minar in 6 storeys.Its height was 250 feet now 238 feet. Measurements of this Minar is that its diameter is 48 feet on ground and 28 feet on the top. Height of $1^{\text {st }}$ storey is 97 feet, $2^{\text {nd }}$ storey is 51 feet in height, $3^{\text {rd }}$ storey is 40 feet high, $4^{\text {th }}$ storey is 26 feet height. Height of $5^{\text {th }}$ storey is of 14 feet, while $6^{\text {th }}$ storey is 12 feet high. (Fig.9a)There is a door on the northern side leading inside the tower to a spiral stairway with 379 steps. Now 238 feet high. The Minar is also provided with diffuse ventilation openings that can be divided in some smaller openings on three levels and larger openings as windows and doors (Ramos et al., 2006).

Its storeys were completed by different monarchs. 1st storey: till its balcony was completed by Aubak and then died 1210, and it remain incomplete. $2^{\text {nd }}$ and $3^{\text {rd }}$ storey wascompleted by Iltumish. After his death 1236 it remains almost incomplete also in reign of Razia \& Ghayas uddin Balban.In 1290 Khilji made 4 th storey.He constructed on its end a kind of umbrella with domical roof supported by pillars. This was not stronger 250 feet height.In the reign of Feroz Shah Tughlak in 1368 , the 4 storey was damaged \& umbrella constructed on pillar almost collapsed.Than Feroz Shah made. He renovate it and reface it with marble slabs leaving lower portions in red sandstone and $5^{\text {th }}$ and $6^{\text {th }}$ storey was added and completed.Height was diminished 238 feet (few said original 240). The cupola on the top was thrown down and the whole pillars was extremely injured by an earthquake and was renovated by Maj. R. Smith Royal Engineer. In 1829 replacing the cupola with Bengal Style Chattri that was removed in 1848 by viceroy Lord Hardinge because it was criticized as not 
according to architectural style of rest of the minar. Now it stands to the left of the entry path and known as smith folly. The staircase on the Northern sides has been closed.

Design on this minar have variations. $1^{\text {st }}$ Storey design is round fluted form alternated with star shape form(Fig.9 c,d.) 2 Storey design is just round fluted form no star shape. 3 Storey design is just star shape. $4^{\text {th }}$ Storey design is completed round. $5^{\text {th }}$ Storey design is round. $6^{\text {th }}$ Storey design is again in round but have grills. Materials of this minar is that 1 st, $2 \mathrm{nd}, \&$ rd Storey is in red sand stone. $4^{\text {th }}$ storey is in marble. $5^{\text {th }} \& 6^{\text {th }}$ Storey is in marble but sometimes incursion of red sandstone $\&$ not exactly balcony in $5^{\text {th }}$ and $6^{\text {th }}$ storey. $1^{\text {st }}$ up to $3^{\text {rd. }}$ Balcony made by step battlement. Projective balconies with stalactite pendentive type of brackets and inscriptional decorative bands heighten its decorative effect. Its completion in 1367.

Leaf masonay is used in the outershell of minar. First three storey external is red color large stones while internal filling is Delhi quartzite large stones. Upper storey external is white marbles while internal is filling of red sandstone. The infill of minar have rubble stonework that stones either from the demolished temples. Central shaft is also of rubble masonry along facing quartzite stones. The mortar material was mixture of lime and brick powder. The outershell thickness $3 \mathrm{~m}$ at base while reduces at top upto 0.6m (Chandran, 2005; Ramos et al., 2007). ${ }^{39}$

Cause of its construction maybe that Islamic traditions as in Iraq \& Iran mosque part is minar for muezzin.( Mughal add 4 miners). Aibak decided to spread Islam and god has gave him power as ruler to spread Islam. So he made it symbolically. And made justice with Muslim and Non-Muslim.On such place where the shadow of god spread from east to west. Its shadow made clear.Tower of victory to show Delhi conquered by Muslims.Although there are many theories either its Aiubak contribution or not but one thing is clear that this Qutab Minar shape is similar to that of Jam Minar situated in Shahrak District ( Ghor) in Afghanistan and is of 65 meter height . It completed in 12th century. This Firuzkoh place was the summer capital of Ghorid Dynasty ${ }^{40}$ (from where Qutbuddin Aibak came) (Fig.17a,b).

Construction of Balcony's one can observe that this minar haveprojected balconies supported by stone brackets. The balconies are supported by stalactite vaulting, represented by clusters of miniature arches with brackets in between (like honeycomb) (Fig.10a). The balustrade 
around the balcony originally showed merlons called kanjuras . The minaret Sir George Birdwood observes as the one original feature the Saracens contributed to architecture.

The Analysis of Design of Qutab Minar explains thatthe design variety contains the calligraphy,geometry and foliation (Fig.11c). One can easily observe beautiful calligraphy on the minar.On the shaft of the Qutb minar, 1 st storey have 4 bands of calligraphy which are run parallel to each other. $2^{\text {nd }} \& 3^{\text {rd }}$ storey, there are 2 bands. Each on the surfaces of the Qutb minar. These calligraphy has been chiseled out in a very boldly manner which stands out in the form of high relief. Intricate calligraphy at minarlooks like an upside-down thin triangle, the pattern carries on throughout. (Fig.11a). The contents of all these calligraphy are the praise of the master of Aibak, Shahbudden Muhammad Ghori.The praise of its creator Qutb ud din Aibak. The reason why Qutb minar was erected and Islamic Calligraphy. Calligraphic inscriptions form regular bands throughout the Qutab Minar (Fig.11 a,b).Manyletterings in Arabic \& Nagari character are seen as wide encircling bands in plain fluted masonry of minar. This inscription reveals the history of Qutb. Bands inscribed with Naskhi lettering. Here again calligraphy with floral buds in end that appeared before in Qutab mosque by Hindu mansions during Aubak times (Fig.10b).

Stone calligraphic bands both linear and circular, proclaim the word of god on the façade. Such inscriptions are Quranic and give meaning to building by clarifying its function.

Undulating bands of carving carry the Quranic message around the base of the Qutb minar. Rhythm of verses themselves.

Geometry is another feature that can be easily seen in its decoration. Islam transformed geometry into a major art forms, using circle as basics for the generation of patterns. Principle of repetition, symmetry and change of scale to create a bewildering variety of effects. Optical effects achieved by negative and positive areas. Patterns are rendered visible from a distance by contrasts of plane which permit the play of light and shade. The star, six, eight, sixteen or more points is one of the fundamental and ubiquitous shapes of Islamic geometrical design. The base has 27 conical edges and 27 circular ones. Calligraphy is closely linked to geometry. In Arabic it is referred to as the geometry of line.

Foliation designs are also present for the enhancement of this miner. The classical vine and scroll motifs from naturalism to fully abstract art of the arabesque.Pattern symmetrically repeated ad infinitum. Design of each surface can be discerned and patterns are so complex that are only distinguishable by the rhythm they set up when they are repeated. The first 
storey depicts the mixture of Hindu and Muslim aesthetics with minute floral patterns and undulating outlines, bell designs also present along with Qur'anic verses. Vine scroll also carved with other motifs. Bell and chain local motif is present on the first floor.

One an easily observe that Qutab minar shape have Seljuk influence. Jam mianr. ${ }^{41}$ (200 feet height) of Afghanistan (1163-1203) have superimposed shaft and polygonal base (figure). Kalan Mosque Bukhara minar (1127) also have tapered shaft that resembled with Qutab minar. But here in qutab shaft were supported by semicircular grooves. (Figure). Compared with that of the mosque, the decoration of the minar is consistently Saracenic ${ }^{42}$ in character. The wide encircling bands carved with Naskh relief give a delicate look to the plain fluted masonry. The most interesting features are its projecting balconies that have early type of the "stalactite "corbelling that is main feature of architecture decoration of Saracenic as similar to the Qutb in India and the Al Hambra in Spain. These series of arch niches in muqarnas like stalactite have difference with the niche shapes found in the temples of that time that explains the synthesis of foreign and local traditional skills used by local craftsman. The higher balconies are less elaborate. These small arches in mini brackets alcove like honeycomb combine gives an intricate look. Kanguras_the stepped battlements like design also present in Qutab Minar second storey and this design also present in tomb of Sultan Kalan (1248 A.D) and Al Azhar mosque Cario.

Tomb of Iltutmish (1235)is another important monument within the Qutb complex build by ruler himself in $1235^{43}$. First it was on the North West corner of Quwat ul Islam. $2^{\text {nd }}$ extension of Khilji it was in the center.Square chamber covered with dome. Excelled in stone carving and has corbel dome.The material of construction is red and grey sandstone and yellow sandstone is in cenotaph (Fig.12a). Double relief stone carving base with geometric or arabesque design and upper Quranic Ayaat. On three sides it has got entrance while western side of wall was close without door but have three mihrabs inside. Its cenotaph is on three step platform. (Fig.12c). It has squinch arches into octagonal forms that seems a half dome built on corbelling rule. An indianlized version of squinch arch used first time here (Fig.13a). Interior is fully covered with minute detail stone carving in every section (Figure) and western wall has blind arch or nich that have stone carving in relief form (Fig.13b). Mostly Saracenic type ${ }^{44}$ decoration and few Hindu forms. Whole interior surface is intricately banded with a diaper of arabesque designs, Quranic inscriptions in both Naskh, Kufic and also Tughra characters which frame the arched openings and recesses and form a frieze to the 
walls. Central mehrab and cenotaph are only in marble but the tomb exterior is simple.Mostly Islamic decoration but few Hindu motifs like bell and chain and lotus appeared here too.

Alai Darwaza is also important monument in the complex. It's the Royal southern gate or Alai gate of the complex and a square domed building of 17.2 meter square having four arch gateways (Fig.14a). Only norther arch is semicircular while others are horseshoe (or Keel arch) true arches. This true arch form that appeared first time here and have 2 keystones. This arch appeared in Muslim monuments before like in Cordoba mosque. ${ }^{45}$ Intricate carvings of geometric patterns and Naskh in red sandstone and marble in the gateway excepting the dome. The arches have a lotus bud fringe design on the underside-features seem to be an influence of West-Asian traditions Hindu element just on the dome and pinnacle of Alai Darwaza. Influence of Seljuk Dynasty. Squinch arch first time introduced in Iltumish tomb but in 1306 used in second time in Alai Darwaza. It has corbelled type dome supported on a walls and dome outer surface is plastered while inside have fine ashlar rings that have small hole covered with small dome (Fig.14b). Except entrance arches the building is plain from outside but heavily decorated from inside in geometric and inscriptions.

Façade a band is present and seems a division is there but not really. White marble, window and screen are present. East of Alai Darwaza is the tomb of Imam Zamin. The exterior have two rows niches on both side of entrance arch that have red sandstone and marble spandrels (Fig.15a). Above have rectangular frames that again have marble niches. The Squinch arches have octagonal semi dome highly decorated shapes. (Fig.15b). The method of construction from trabeat to arcuate is a change that explains the traditional Muslim influence on locals.

Thickness of wall 12 feet. Inside 6 feet each side. Total Length + Breadth+ Height is 42 feet. Diameter is 30 feet from interior. Width is big and have big dome. Pinnacle of Alai Darwaza have hindu motifs. Kalsa and amla (Fig. 14c). The arched entrances and jalis are decorated by fringes of lotus buds and have geometric patterns (Fig.15a). Interior of Alai Darwaza shows the decoration of Seljuk influence at peak ${ }^{46}$ like Seljuk jali and brickwork in Iran.

Some other monuments are also present near the Qutab mosque such as Alauddin's Madrassawhich is situated in south west of mosque.Built around a quadrangular court entered on theNorth through a triple gateway.Alauddin constructed but few historians say it was made by Iltutmish.

Alauddin's Tomb is also present on south side of the court.Its square structure building with no dome now.Only remains of boldly projecting portico left.It was combined to madrassa just like Seljukian tradition (Fig16a) . 
The ruined wall of Qutab Complex still exists. Qutab Minar, Alai Minar, Alai Darwaza, Iltutmish tomb are in better condition but not the mosque.

\section{Conclusion:}

The Qutab complex and the related monuments within the complex provide base of Muslim art \& architecture in the subcontinent and are trend setters. The use of trabeate style in the Qutab mosque and later use of arcuate system in the Alai Darwaza explains the architecture progress and change after the Muslims in Indian architecture. Similarly, from corbelling use to true arches explains the change in construction method. The use of domes, squinch arches and stalactite designs like Muslim Muqarnas but yet with Hindu influence as half octagonal dome like squinch arches in Iltutmish Tomb and stalactite with more minute stone carving details as in the Qutab Minar are different and have temple style decoration explains the local influence on the Muslim art. Though arabesque, geometry and calligraphy were a part of traditional decoration in Muslim art before but in Delhi this was the first time but with change. Here initial works of Hindu mansions during Auabk who were experts in stone carving designs and influence of these craftsmen amalgamation of local style natural decorative elements like floral use, bell shaped designs changed the execution style of Muslim design and use of material. Later though during Iltutmish Muslim craftsmen but again the design is more natural, detailed more relief stone carvings and have soft majestic look, more precise and accuracy if compared with Muslim monuments of other areas of that time. Traditional Muslim designs and regional Hindu style of design \& use of material mixed and formed a new naturalistic executed style with more accuracy. In short, Qutab Complex is the base of Indo-Islamic design art and architecture and the monuments of this complex explains the transition and evolution story of these beautiful well composed majestic designs and architecture. 


\section{List of Figures:}

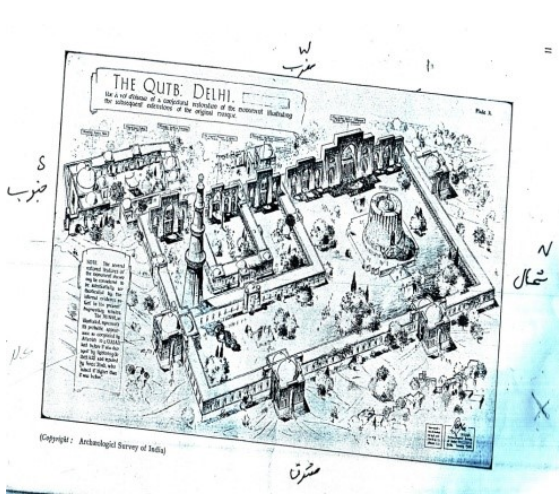

b)

Fig1: Qutab Complex;
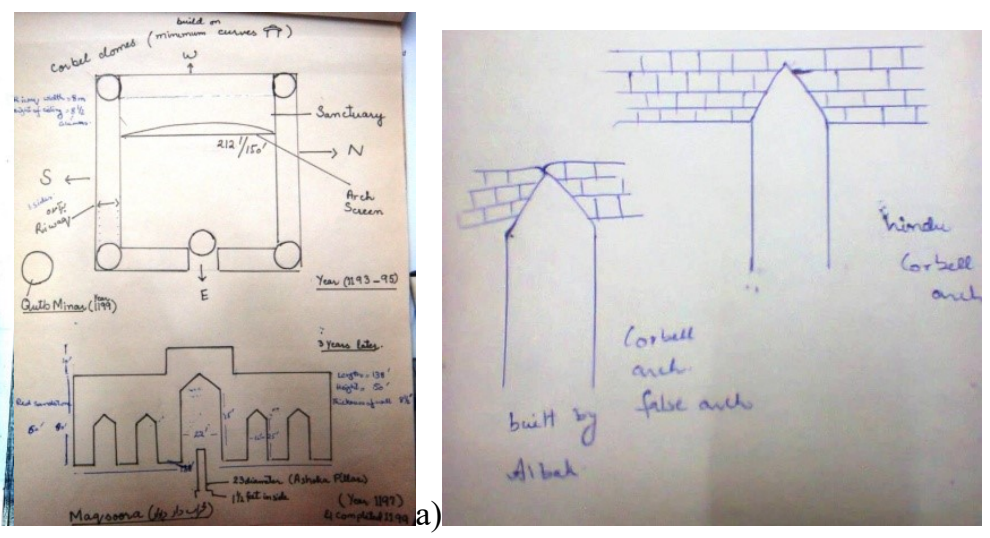

Fig.2: (a) Aubak Contribution, (b): Corbel Arch built by Aubak,

(Source: Percy brown Indian Architecture \& author illustration drawing)
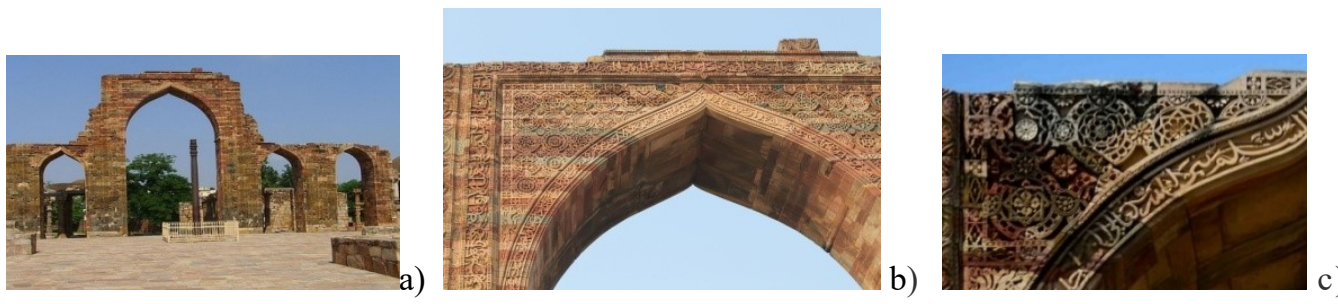

Fig.3: (a) Façade build by Aubak and Iron pillar in front of courtyard (b)Pointed arch (c) Calligraphy on façade gives an impression of upwards to downwards
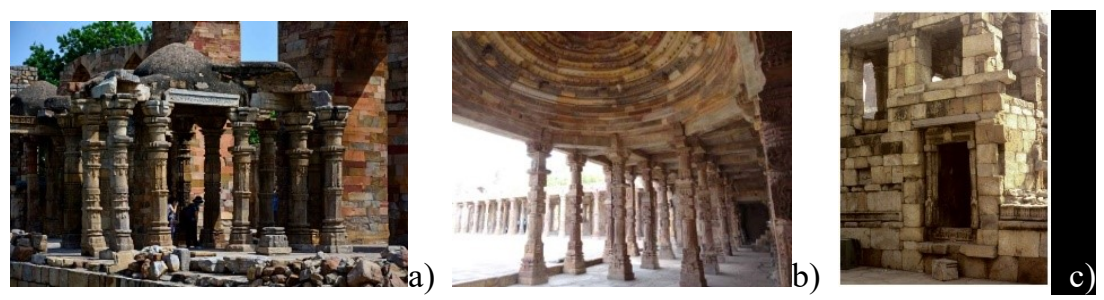

Fig. 4: (a) Prayer hall behind the mosque screen and low curve corbel dome (b) corbel Dome and pillars on east colonnade (c) Private entrance to zenan or

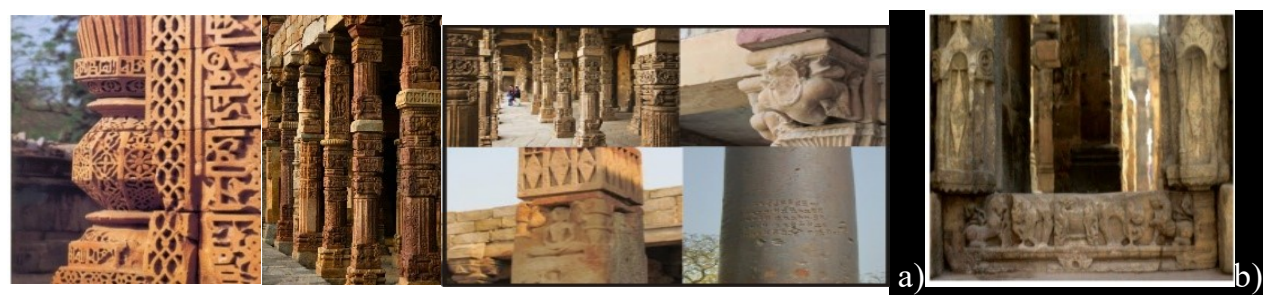

Fig.5: a) Hindu Architectural Motifs \& Hindu deities' on pillars (b) private room with statues

(Source:https://www.sahapedia.org/the-qutb-complex-overview 29-12-2019) 

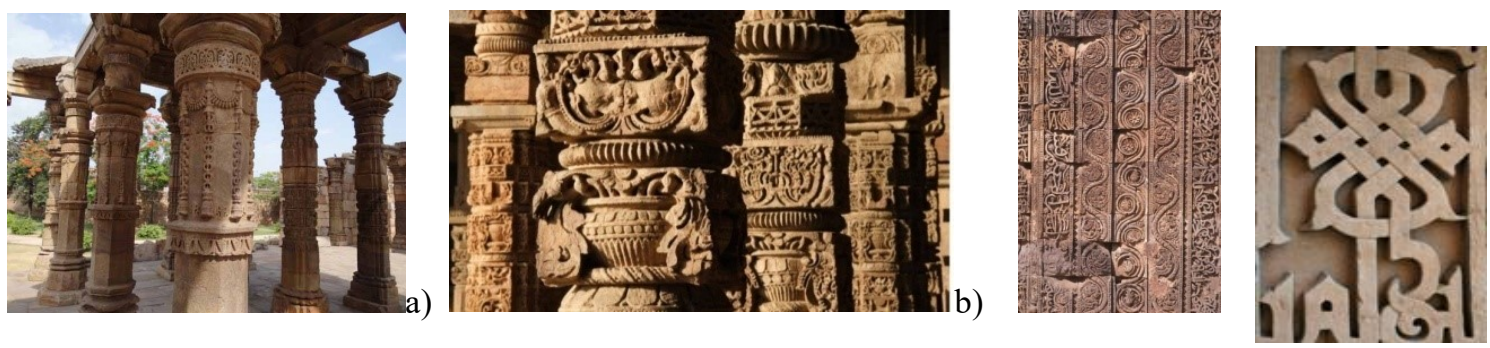

c)

Fig 6: (a) Hanging bells on the prayer hall column (b) Brahmanical motifs like Kalsa and Lotus on pillars (c) Calligraphy and design patterns

(Source: https://archive.org/stream/qutbminaradjoini00page/qutbminaradjoini00page djvu.txt (27-12-2019)
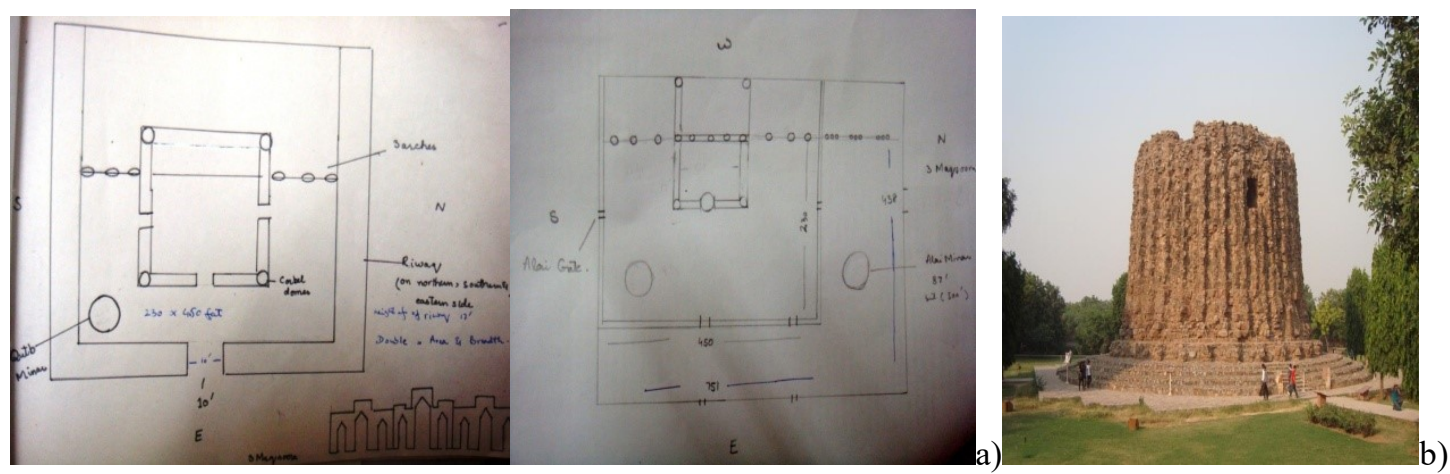

Fig.7: Iltutmish contribution;

Fig.8: (a) Alauddin Khilji contribution in the Qutab complex (b) Alai Minar
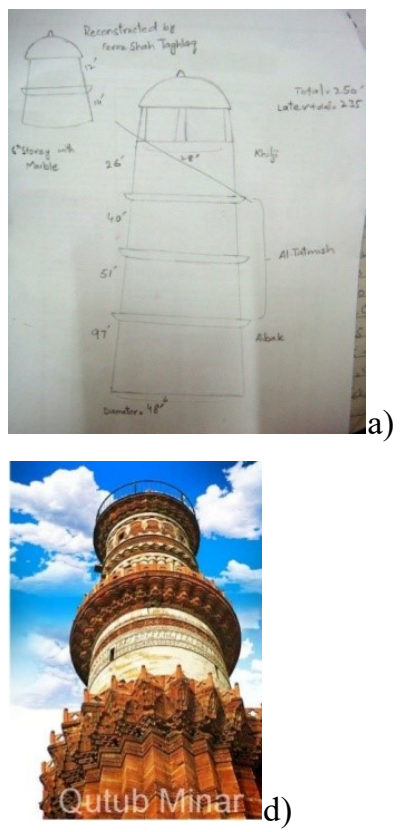

b)

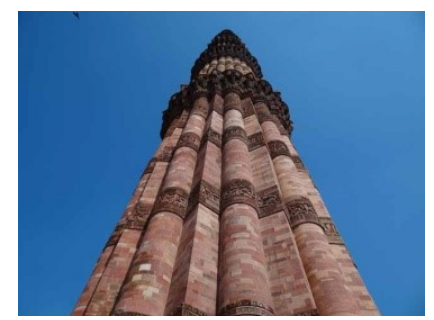

c)

Fig. 9: (a) Measurements of Qutab Minar, (b) Qutab Minar (c) First Storey design (d) upper storey design 


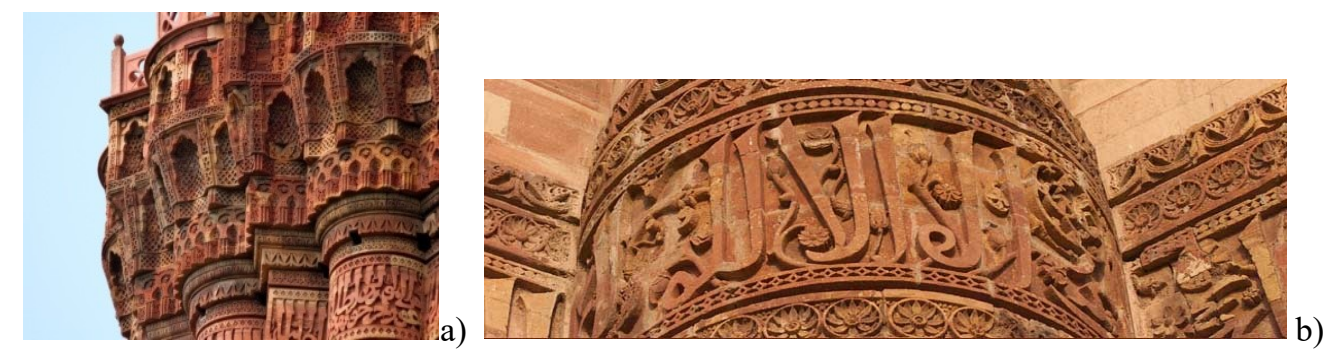

Fig10: (a) Balcony design, closeup stalactite pattern (b) design variety

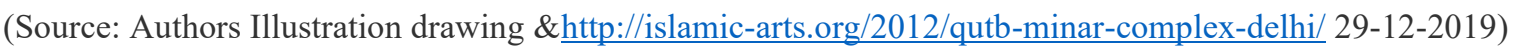
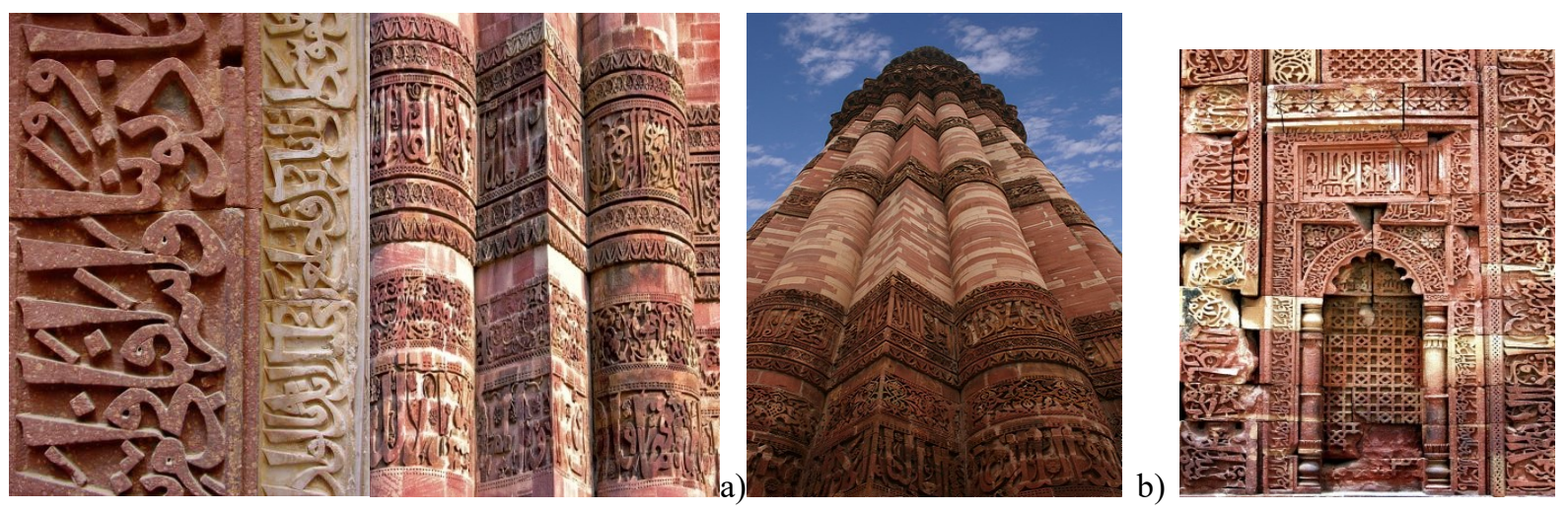

c)

Fig.11: (a) Intricate calligraphy (b)Kufic Calligraphic incription form regular band (c) geometry,foliation and calligraphy
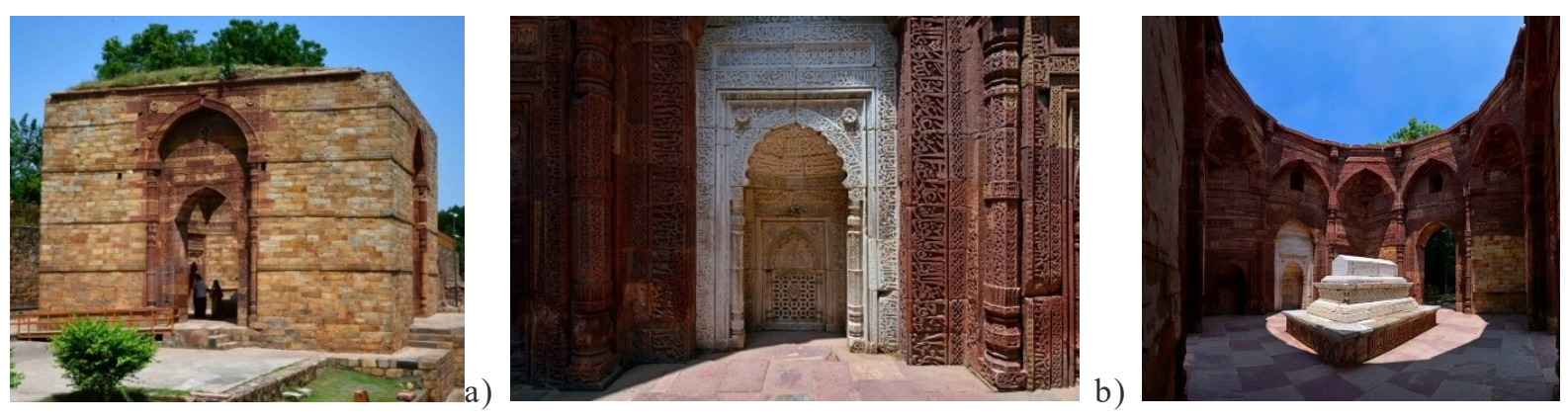

c)

Fig.12: (a) Iltutmish Tomb (b) Inside main arch (c) Tomb open ceiling \& cenotaph on 3 step platform
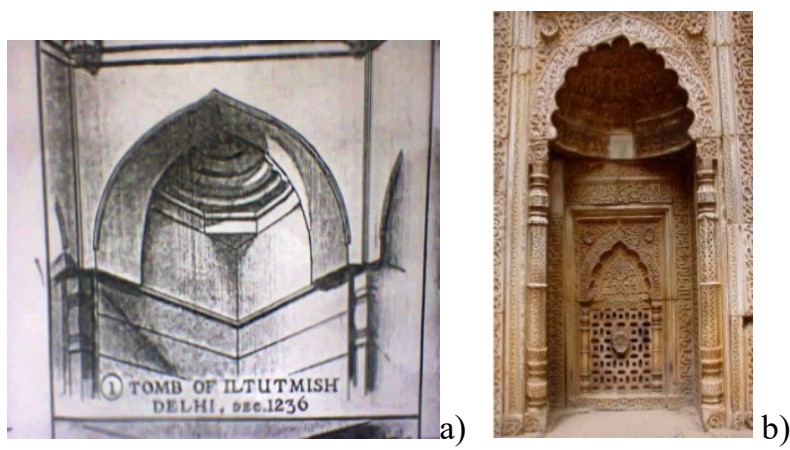
Fig.13: (a) Octagonal form Squinch arches in Illtutmish Tomb (b) niche \& relief form stone carving in Iltutmish tomb
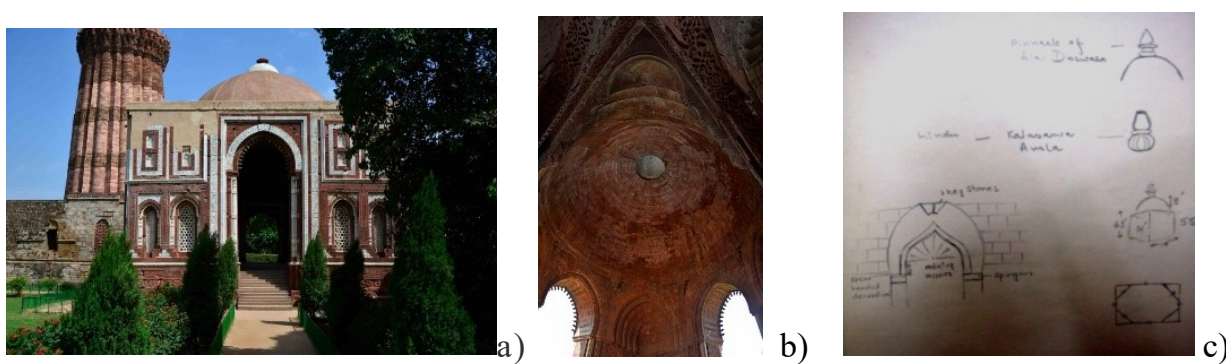

Fig.14: (a) One of the Exterior wall of Alai Darwaza (b) Interior dome ceiling (c) two keystones, measurement and pinnacle of Alai darwaza

(Source: Percy Brown, Indian architecture, authors illustration drawing)
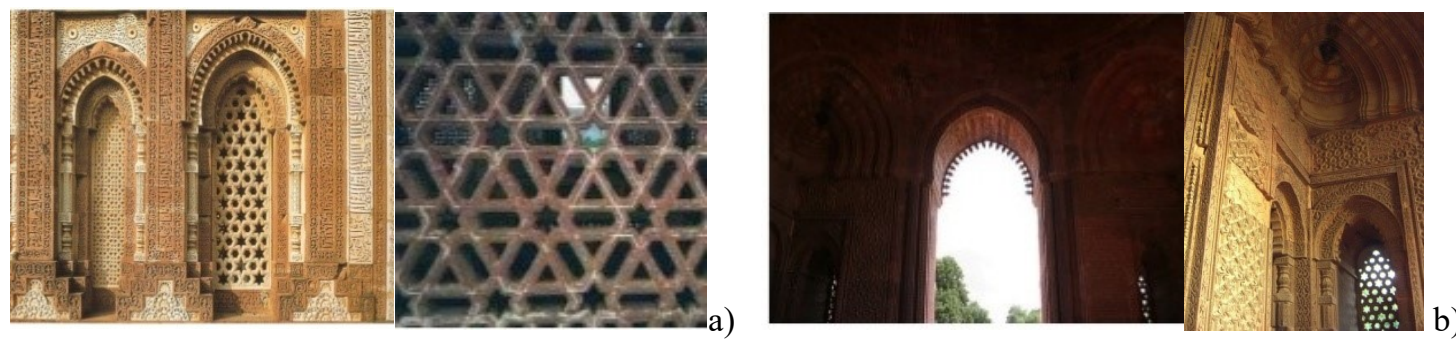

Fig. 15: Façade of Alai Darwaza (b) Interior of Alai darwaza
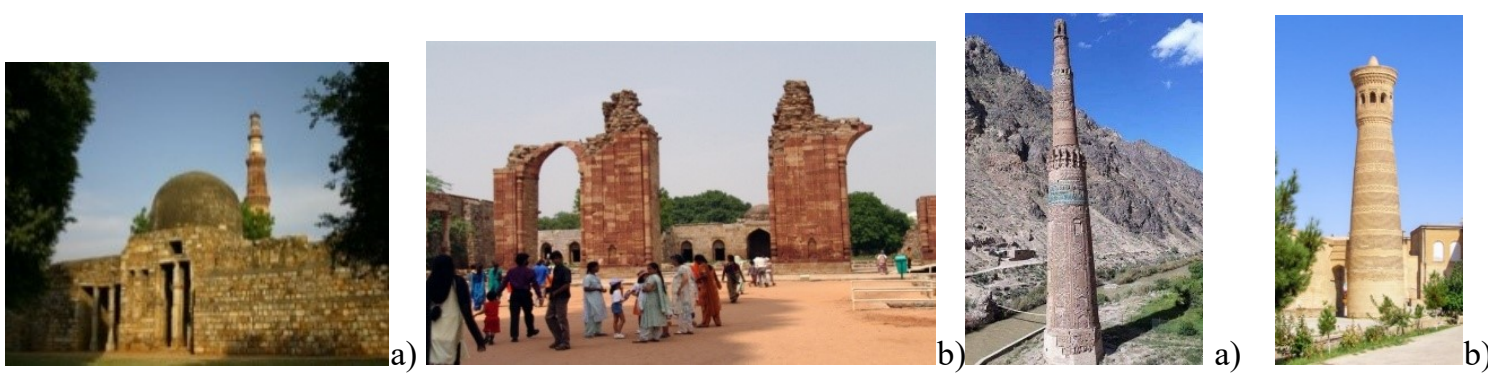

Fig.16: (a)Alauddin's Madrassa Tomb (b) ruins of Qutab complex ;Fig.17: (a)Jam Minaret, Afghanistan (b) Kalan Mosque Minaret (Bukhara)

(Source: http://asi.nic.in/asi_monu_whs_qutbminar.asp 29-12-2019)
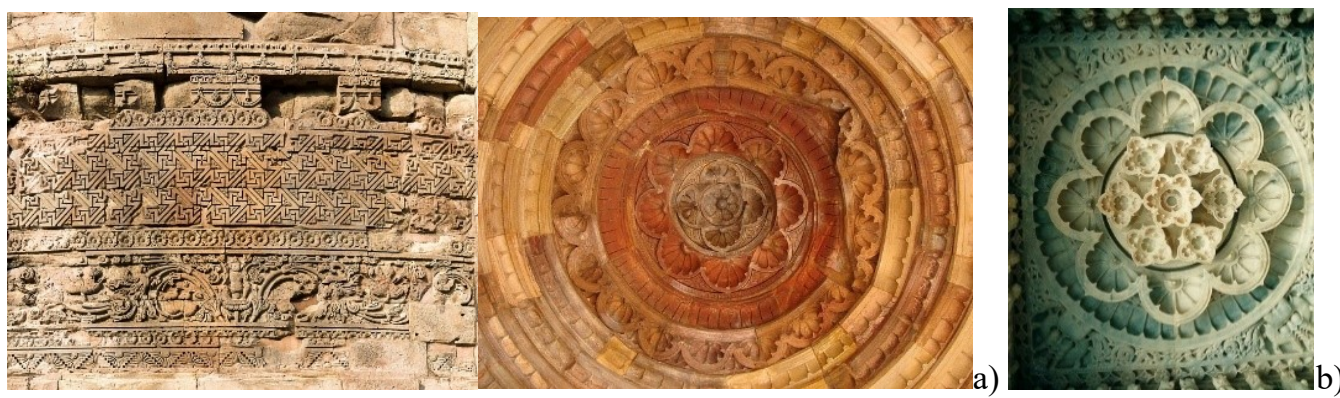
Fig.18: Design patterns on Dhamekh Stupa, closeup Sarnath $7^{\text {th }}$ century;Fig.19: a) qutab mosque ceiling with (b) Moun Abu Dilwara Jain temple

(Source:https://www.shutterstock.com/image-photo/architectural-detail-on-dhamekh-stupa-sarnath-1023171604 29-12-2019)

\section{Bibliography:}

- Brown, Percy.1944.Indian Architecture (Islamic Period), Bombay: Taraporevala sons \&Co Private Ltd.

- Ewer, Walter. 1832 "An Account of the Inscriptions on the Cootub Minar, and on the Ruins in Its Vicinity, ” Asiatic Researches 14. Pdf. 28-12-2019

- Napier, Lord. 1870. Modern Architecture in India.” The Builder 28. pdf.28-12-2019

- Sharma, S. D. 1937.The Crescent in India. Bombay: Bharatiya Kala Prakashan.

- Chagatai, Muhammad Abdullah. 1961. Turkish Architectural Ornament in IndoPakistani Architecture, First International Congress of Turkish Art, Ankara, 19th-24th October, 1959 (Ankara, 1961).

- Kuban, Do an. 1985.Muslim Religious Architecture 2: Development of Religious Architecture in Later Periods. Leiden: Brill Academic Publishers.

- Ettinghausen, Richard, and Oleg Grabar. 1987.The Art and Architecture of Islam 650-1250 .New York: Yale University Press.

- Willis, Michael D.1985. An Eighth Century Mihrab in Gwalior, Artibus Asiae 46.pdf.

- Havell, E. B. 1972.The Ancient and Medieval Architecture of India: A Study of IndoAryan Civilisation. New Delhi: SChand.

- Fergusson, James.2013. History of Indian and Eastern Architecture. London: Cambridge University Press.

- Shokoohy, Mehrdad. 2003. Muslim Architecture of South India: The Sultanate of Macbar and the Traditions of the Maritime Settlers on the Malabar and Coromandel Coasts [Tamil Nadu, Kerala and Goa].London: Routledge.

- Nath, R.1983..Islamic architectureand culture inn India.Apt Books.

- Chughati. M. Abdullah. The Badshahi Masjid, History and Architecture.Lahore:Kitabkhana. 
- Barry Flood, Finbarr.Objects of Translation: Material Culture and 'Hindu-Muslim' Encounter, 800-1250. London: Princeton University Press.

- J.A.2011.Guide to the Qutab Delhi. India: Nabu Press.

- Ruggles,D. Fairchild,2000. Gardens, Landscape and Vision in the Palaces of Islamic Spain. University Park: Penn State Press.

\section{References:}

1 Tärikh i-Fakhru-ud-din Mübārak Shāh. p.31

2 Percy Brown, Indian Architecture.p.10.

3 Ewer,Walter. An Account of the Inscriptions on the Cootub Minar, and on the Ruins in Its Vicinity. pp.480-89.

4 Napier,Lord. Modern Architecture in India," The Builder 28 (1870), p.722

5 Sharma,S. D.The Crescent in India.p.63

${ }^{6}$ Chagati, Muhammad Abdullah. Turkish Architectural Ornament in Indo-Pakistani Architecture, p.75.

7 Kubab, Do an.Muslim Religious Architecture: Development of Religious Architecture in Later Periods .p.15.

8 Cited in R. W Hamilton, "Keppel Archibald Cameron Creswell," Proceedings of the British Academy 60 (1974): 6. Reprinted in Muqarnas 8 (1991): 130.

9 Kuban,Doan.Muslim Religious Architecture: Development of Religious Architecture in Later Periods.p.15.

10 Ettinghausen, Richard and Oleg Grabar.The Art and Architecture of Islam 650-1250. pp. 291-293

11 Willis, Michael D. An Eighth Century Mihrab in Gwalior. pp.244-45

12 Havell, E. B.The Ancient and Medieval Architecture of India: A Study of Indo-Aryan Civilization. p. 218

13 Fergusson, James. History of Indian and Eastern Architecture. p. 501

14 Chagatai,M.Abdullah. Turkish Architectural Ornaments. p.76

15 Page, Memoir, 8.

16 Shokoohy, Mehrdad. Muslim Architecture of South India. p. 235

17 Brown, Percy.Islamic architecture: Islamic Period.p.11.

18 Ibid.p. 13

${ }^{19}$ Nath,R. Islamic architecture. p.97

${ }^{20} \mathrm{https} / / /$ archive.org/stream/handbookofindian00have/handbookofindian00have_djvu.txt

$21 \mathrm{https} / / /$ www.academia.edu/7334694/Asar_ul_Sanadid--Fatima_Quraishi

$22 \mathrm{https} / / /$ archive.org/stream/handbookofindian00have/handbookofindian00have_djvu.txt

23 Brown,Percy. Islamic architecture: Islamic Period. p.15

${ }^{24}$ https://www.academia.edu/7334694/Asar_ul_Sanadid--Fatima_Quraishi

${ }^{25}$ Chemical analysis if sir Robert Hadfield Guide to the Qutab Delhi, p. 7

$26 \mathrm{https} / / /$ archive.org/stream/handbookofindian00have/handbookofindian00have_djvu.txt

27 Tärikh-i-Farishtā-Vol 1.p .63.

28 Brown,Percy. Islamic architecture: Islamic Period. p.18

29 Corbelling arches are constructed with layering of blocks and rounding edges in arch forms Percy Brown

${ }^{30} \mathrm{https} / / /$ www.academia.edu/7334694/Asar_ul_Sanadid--Fatima_Quraishi https://www.wmf.org/sites/default/files/article/pdfs/A\%20Walk\%20around\%20the\%20Qutb\%20Complex.p df

$32 \mathrm{http} / / / \mathrm{www}$. sciencedirect.com/science/article/pii/S2095263513000216 1-12-2015

${ }^{33}$ Chughati. M. Abdullah. The Badshahi Masjid, History and Architecture. p.24

${ }^{34}$ Kufic heavy script, tughra stylized

${ }^{35}$ https://www.academia.edu/7334694/Asar_ul_Sanadid--Fatima_Quraishi

${ }^{36}$ Barry Flood, Finbarr.Objects of Translation: Material Culture and 'Hindu-Muslim' Encounter, 800-1250 .p. 198

37 J.A. Guide to the Qutab Delhi.p. 4

38 Ibid 
68 Perennial Journal of History (PJH), Vol, 1, No. 1

39

https://www.researchgate.net/publication/267690331_SEISMIC_ASSESSMENT_OF_THE_QUTB_MINA R_IN_DELHI_INDIA

$40 \mathrm{https}: / /$ vikramjits.wordpress.com/2012/11/14/untold-story-of-the-qutub-minar/

${ }^{41}$ Fergusson, James. History of Indian and Eastern Architecture, 501.

${ }^{42} \mathrm{https} / / /$ starsinsymmetry.wordpress.com/2010/02/23/study-difference-between-muqarnas-and-mocarabe/

${ }^{43} \mathrm{https} / / /$ archive.org/stream/qutbminaradjoini00page/qutbminaradjoini00page_djvu.txt

44 J.A. Guide to the Qutab Delhi.p. 11

45 Ruggles 2000; Arnold 2017.p. 20.

46 J.A. Guide to the Qutab Delhi.p. 4 